\title{
Between African and American Neo-Pentecostalism: An Examination of the Link, Influence, Merits and Demerits
}

\author{
Daniel Orogun \\ https://orcid.org/0000-0001-8642-0724 \\ University of Pretoria \\ arcorogun2@gmail.com
}

\author{
Jerry Pillay \\ https://orcid.org./0000-0001-5188-3550 \\ University of Pretoria \\ jerry.pillay@up.ac.za
}

\begin{abstract}
This article is based on a research study that investigated the influence, merits and demerits of the link between African and American Neo-Pentecostalism. The study employed a qualitative research method through which 40 contemporary African Neo-Pentecostal leaders (drawn from South Africa and Nigeria) were interviewed. Additionally, given that most charismatic faith and miracle African Neo-Pentecostal leaders in focus took their roots from American Neo-Pentecostalism, two medical doctors (who equally serve as African Neo-Pentecostal lay ministers), were interviewed to investigate a mother-child link. This was done to ascertain the possibility of existing traits being passed on. Alongside the historical link, the interview findings show that African Neo-Pentecostal leaders display a continuous link and traits from their American Neo-Pentecostals mentors. Thus, they exhibit such traits in theology and other practices. Subsequently, the research study established that the influence of American Pentecostalism engenders more demerits, and the researchers proposed the need to constantly de-emphasise the Americanisation of the gospel in Africa. In order to achieve this, some relevant recommendations were made, proposing that African Neo-Pentecostals need to be separated from a toxic foreign culture and should "self-exist," thereby making room for African uniqueness in contemporary Neo-Pentecostal practices.
\end{abstract}

Keywords: African-Pentecostalism; American-Pentecostalism; influence; leadership; merits; demerits; intra-religious threats; dialogue; self-exist; link

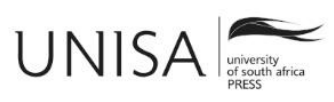

Studia Historiae Ecclesiasticae https://unisapressjournals.co.za/index.php/SHE/index Volume 47 | Number $3|2021| \# 8550 \mid 18$ pages 


\section{Introduction}

The influence of religion on individuals' or groups' social behaviour and contribution to the community is undoubtedly significant. As Harrison puts it, our world contains a striking diversity of religious traditions, yet these traditions have a "family resemblance approach" (Harrison 2006, 1, 20). A perfect example is the Christian faith, which has an intra-faith resemblance, yet it is divergent in practices. Among different groups within the Christian faith, are the Neo-Pentecostals. They have emotional and dramatical traditions that fit into the description of Goerge Lindbeck, who claims that religion is both experimental and expressive (Lindbeck 1984, 16; cf. Robinson 2000, 1). Today, Neo-Pentecostalism, with massive followership across the globe, is influencing the religious and social culture of the world. Likewise, Harvey $(1996,6-8)$ notes that Pentecostalism is the fastest growing stream of Christianity in the world today, as it is reshaping religion in the twenty-first century. According to the BBC (2009, 3 of 16), there are currently between 250 to 500 million Pentecostals around the world, who make up more than 10\% of all Christians. Likewise, Engelsma (2001, 1 of 14), calls Pentecostalism a "third force" in Christendom. Obviously, the numbers must have gone higher between the years 2001-2009 and 2021. Roger (1990, 885) calls it "the single-most-significant development in twentieth-century Christianity."

Furthermore, the Institute for Advanced Studies in Culture (IASC, n.d., 1 of 2) asserts that the real-world impact of Pentecostalism, both positive and negative, extends into all realms of political, economic and social life. Thus, it can be said that beyond political and economic realms, the influence of Neo-Pentecostalism may cut across regions, environments and religious cultures. Correspondingly, on the background of possible influence, this article seeks to investigate the influence of American NeoPentecostalism, its merits and demerits on African Neo-Pentecostalism. That is the purpose of this article. Subsequently, the article clarifies conceptual words and gives a brief history and historical link. The next section focuses on the evidence of the link as seen from the field interviews. Lastly, we discuss the merits and demerits respectively, while articulating the recommendations and conclusion.

\section{Clarification of Concepts}

\section{Pentecostalism}

Neo-Pentecostalism emerged in the 1950s and 1960s, but those versions referred to in this article are the newer or more contemporary African versions from the 1980s to date. Specifically, this article focuses on the faith, healing, miracles and prosperity movement that emerged from the 1980s to date. This does not mean that other movements, like the Aladura movement, are not considered relevant. Thus, Neo-Pentecostals in this article will refer to the newer contemporary faith, healing and prosperity movement. However, the article will briefly define and explain Pentecostalism in general. 
Pentecostalism may be defined as a modern charismatic reformation movement with a distinctive theology of spirit baptism that gives doctrinal priority to the gift of tongues (Towns 2006, 2 of 3). Asamoah-Gyadu (2006, 1 of 1) describes it as a stream of Christianity that emphasises personal salvation in Christ as "a transformative experience wrought by the Holy Spirit." Subsequent to that initial experience, such pneumatic phenomena as "speaking in tongues," prophecies, visions, healing, miracles, signs and wonders have come to be accepted, valued and encouraged among members as evidence of the active presence of God's Spirit. Furthermore, the experience on the day of Pentecost in Act chapter 2, appears to be where the Pentecostals picked their name from. The Institute for Advanced Studies in Culture (IASC n.d., 1 of 2) reports that at least one in four Christians in the world is affiliated with this faith. This group believes in freedom of worship as the spirit leads and directs. Kojok (2007a, 1-2 of 5) points to the main characteristic of the group as an emphasis on the Holy Spirit through speaking in tongues (glossolalia or xenoglossia).

\section{African Pentecostalism}

Some African scholars argue that African Pentecostalism is indigenous foundationally, but this position may be contestable. Kalu (2009, 10) maintains that African Pentecostalism did not originate from external change agents and networks, but from an indigenous worldview. Kgatle $(2017,4)$ explains that African Pentecostalism is a "part of Christianity in Africa that is influenced by a Pentecostal movement that started in the early church of the Apostles recorded in the book of Acts 2:1-4 and the Pentecostal movement that started in the United States of America." In other words, African Pentecostalism is a product of both indigenous and foreign experiences. However, as earlier stated, this article will focus on the Neo-Pentecostal movement built on the foreign experience of the contemporary American faith, miracle and prosperity NeoPentecostals.

\section{American Pentecostalism}

The history of American Pentecostalism is largely heralded as the Azusa Street experience, but it started long before then. Bruner $(1970,37)$ asserts that the root of Pentecostalism is not only in the Black American understanding and practice of Christianity, but also in the American Holiness Movement that grew out of Wesleyan Methodism. He goes further to identify eighteenth-century Methodism as the mother of the nineteenth-century American holiness movement, which later progressed into twentieth-century Pentecostalism. MacRobert $(1988,37)$ agrees with Bruner when he argues that Pentecostals owe a great deal of their theology to Wesleyan Methodism. Building on this existing foundation, the Neo-Pentecostals have continued to develop and metamorphosise into prosperity, healing and miracle movement in the twenty-first century. 


\section{Historical Evidence of the Link}

History helps us to appreciate the past, analyse the progress of the present and perhaps predict the future. According to Synan (2019, 2 of 14), the Pentecostal movement may have had its beginning in the United States, but it owed much of its basic theology to earlier British perfectionistic and charismatic movements. At least three of these, the Methodist/Holiness movement, the Catholic Apostolic movement of Edward Irving, and the British Keswick "Higher Life" movement, prepared the way for what appeared to be a spontaneous outpouring of the Holy Spirit in America. Thus, revival and renewal experience began among the British perfectionists, while the charismatic movement had full expression during the Azusa experience (see BBC 2009, 8 of 16). The first "Pentecostals" in the modern sense appeared in the city of Topeka, Kansas, in a Bible school conducted by Charles Fox Parham, a holiness teacher and former Methodist pastor. Agnes Ozman, one of Parham's Bible school students, was the first person who spoke in tongues on the first day of the new century, January 1, 1901. More specifically, BBC (2009, 9 of 16) reports that she spoke in Chinese (xenoglossolalia) and did not speak English again for several days. By the 3rd of same January, over a dozen students in the Bible school spoke in tongues. As Ozman's story travelled around the world, it sprung up the Pentecostal theology called Bible evidence of the baptism of the Holy Spirit. This story was instrumental in bringing people from different denominations together. Additionally, the Ozman and Parham's Bible school experience was followed by the Azusa Street revival, in Los Angeles, led by the African-American preacher William Joseph Seymour, who had studied with Parham. According to the Azusa Street Mission Report (n.d.), in 1972, Sidney Ahlstrom, a church historian at Yale University, states that Seymour was "the most influential Black leader in American religious history" (Azusa Street Mission Report n.d.). Seymour, along with Charles Parham, could well be called the "co-founders" of world Pentecostalism. At some point, Seymour preached and his congregation spoke in tongues. Synan (1980) accounts that Seymour was the son of a former slave, raised as a Baptist, and he later joined a radical holiness church. Subsequently, he believed in divine healing, the rapture of the saints and premillennialism, justification by faith and "sanctification as a second work of grace." With Seymour's background, American Pentecostalism was linked to an initial experience of the Wesleyan holiness movement and the likes. The link did not stop in America, but was extended to Africa.

Moreover, during the Asuza revival Seymour began the "Apostolic Faith Mission" with prayer meetings. Synan (2019, 8 of 16) reports that the Azusa Street Apostolic Faith Mission conducted three services a day, seven days a week, where thousands of seekers spoke in tongues. Subsequently, the experience spread rapidly around the world until Pentecostalism became a major force in Christendom. Currently, Apostolic Faith Mission churches are spread all over Africa, an indication of the missional influence of American Pentecostalism in Africa. In order to establish historical evidence of the link, an important question will be: How did Neo-Pentecostalism find its way into Africa? In order to answer this question, some historical analyses have been made below. 


\section{Slavery and Poverty}

Coincidentally, Pentecostalism began at a time when the Blacks in America were labouring under the weight of poverty, oppression and slavery. As a message of hope, a "Black Theology" for African-Americans, called the theology of suffering, was developed. According to Ellis (2013, 2 of 3), the southern Blacks embraced intuitive theology because they were enslaved and denied access to formal education. This contextual theology of hope then became the alternative to alleviating slave stress. Correspondingly, this Pentecostal gospel of hope appealed to the poor as they found a religion that allows emotional expression and yearnings for freedom. Subsequently, Pentecostal theology appealed to Africans in their quest for freedom from poverty and demonic powers. Freeman $(2015,6,15)$, agrees that Pentecostalism brought transformations from what the Africans were subjected to over the years. There was no resistance to this theology of hope, as most Africans felt it was an answer to their prayers. The people imagined Christ through the Pentecostal preachers as "Allpowerful" who could save them from their spiritual and social calamities (cf. Kalu 2002, 110-137). It is safe to opine that Pentecostalism commenced among the poor in North America, and it then spread to nations like Africa and South America where widespread poverty and inequality were rooted (see Sundkler 1976, 318-319; Quayesi-Amakye 2016, 77).

\section{The Similitude of Worship Culture}

Among Africans, traditional music and religion are interconnected. Traditional worship involves dancing at the shrine and offering sacrifices to deities. Synan (2019, 8 of 15), cites that the Azusa Street movement had a merger of White American holiness religion with worship styles derived from the African-American Christian tradition, which had developed since the days of chattel slavery in the south (see BBC 2009, 11 of 17). In other words, worship style, dancing and shouting were synonymous with the African experience before the advent of Pentecostalism. Consequently, acceptance and acclimatisation became easy. It is then logical to suggest that similitude of worship culture allowed American Pentecostalism to flourish in Africa. Little wonder, to date, most contemporary African Neo-Pentecostal churches maintain Western music styles, songs and lyrics in worship.

\section{Power Evangelism vis-à-vis African Spiritual World View}

Kit (2019, 2-3) calls the theology of the Pentecostals "classical and most attractive to Africans as a result the manifestations of divine healing, spiritual gifts, discernment of spirits, prophecy, songs, prayers, communion and giving." Asamoah-Gyadu (2006, 4 of 6) asserts that healing and deliverance have become some of the most important expressions of Christianity in African Pentecostalism, as the underlying worldviews of the practice resonate with African philosophical thoughts. Jones $(2015,2)$ argues that Africans easily subscribed to the "theory of power evangelism." Perhaps, the people could find everything they needed in terms of spiritual help from the visiting American power evangelists. It then suffices to accept that Africans' initial spiritual worldview 


\section{Orogun, Pillay}

relating to demonic attacks, witchcraft operations, and so forth, and their desire for healing, miracles and deliverance made access easy for American Pentecostalism operations in Africa. Consequently, thousands of African Neo-Pentecostal power evangelists have emerged and are sustaining the practices of their American mentors across Africa.

\section{Pentecostal Missionaries' Invasion and their Relationship with African Pentecostal Leaders}

Many missionaries visited different parts of Africa. In South Africa, it was evident that American Pentecostalism birthed a great movement. After the Azusa experience, Anderson $(2001,93)$ gathers that in the late 1990s, Pentecostals comprised $10 \%$ of the population, with the largest denominations being the Apostolic Faith Mission, Assemblies of God, and the Full Gospel Church of God. The Black Zionist and Apostolic churches, which constitute the majority of South Africa's African Instituted Churches (AICs), account for an additional $30 \%$ or so of the population. This record presents the Apostolic Faith Mission as the leading American Pentecostal Mission in Africa and supports the notion that there was a link - and indeed a continuous linkover the years. This article will now briefly look at the works and influence of a few American Pentecostal missionaries in Africa.

\section{John G. Lake in Southern Africa.}

John G. Lake was considered the father of African Pentecostalism. History has it that he was under the ministration of Parham, in whose Bible school Ozman spoke in tongues and was later recruited among over 500 missionaries who spread the gospel to the entire world. Prominent among his exploits was his mission to Africa. Synan (2019, 12 of 15) puts it succinctly: "African Pentecostalism owed its origins to the work of John Graham Lake (1870-1935), who began his ministry as a Methodist preacher but later prospered in the business world as an insurance executive." In 1898, his wife was miraculously healed of tuberculosis under the ministry of Alexander Dowie, founder of the "Zion City" near Chicago. Under Parham and Alexander Dowie, John G. Lake experienced the work of the Holy Spirit and developed the gift of divine healing. He penetrated Africa as a power evangelist involved in healing and deliverance. Coakley (2014, 1 of 2) profiles that when the Ebola virus erupted in Africa, killing thousands of people without any cure, John G. Lake took up the challenge and performed healing. When asked by the medical world how he did it, he said: "I have the life of God in me, every virus that comes in contact with me dies." When an inoculum filled with Ebola viruses was placed in his palm, all viruses were dead upon contact with him (Contra. Morton 2017, 1-16). In reference to Rhodes, Synan, notes that Lake's message swept Africa, his evangelistic exploits were the most influential and enduring of all the South African Pentecostal missions' endeavours. He has done more towards South Africa's future peace than any other man. Synan further notes that perhaps the highest accolade was given by no less a personage than Mahatma Gandhi, who concluded that "Dr Lake's teachings will eventually be accepted by the entire world" (Synan 2019, 13 of 15). Such 
power evangelists could not be resisted in Africa. Thus, followership multiplied, and many African Neo-Pentecostals were influenced and recruited to learn and spread the Pentecostal theology across towns and villages in Africa.

\section{T. L. Osborn's Influence on Archbishop Benson Idahosa}

Several Neo-Pentecostal American evangelists continue to visit and influence African preachers (see Isiramen 2010, 307). Benson Idahosa, who was named the father of Pentecostalism in Nigeria, was influenced by a few of them. Relate (2016) opines that Idahosa had strong links with Billy Graham, T. L. Osborn, Kenneth Hagin, Benny Hinn, Reinhard Bonnke, Morris Cerullo, and Oral Roberts, amongst others. His wife, Margaret Idahosa, confirmed that T. L. and Daisy Osborn influenced Benson Idahosa to recognise the ministry and ordination of women. Consequently, Margaret was ordained. Afterwards, Margaret started the African Christian Women Fellowship International. The fellowship recognised, empowered and ordained women to participate fully in ministry across Africa. Daisy Osborn became the life Adviser of the African women fellowship (Idahosa 1995). Obviously, Margaret and Benson's teachings and practices were connected to the American Neo-Pentecostals. As the founding President of the Pentecostal Fellowship of Nigeria (PFN), he influenced prominent Nigerian pastors like Ayo Oritsejafor, Bishop David Oyedepo, Felix Omobude, Fred Addo and Chris Oyakhilome. After his demise, his protégés continue to interact with American Neo-Pentecostal leaders. A perfect example is Chris Oyakhilome's relationship with Benny Hinn.

\section{Duncan Williams and the American Pentecostal Influence}

Although Kojok (2007b, 1-2 of 4) reports that Emmanuel Enoch Amino Agbozo was the pathfinder of the rapid spread of Pentecostalism in the late 1970s and early 1980s, he argues further that credit for moving the charismatic trend from the periphery to the centre of Christianity in Ghana, must ultimately go to Nicholas Duncan Williams. His influence was credited to his mentor, Benson Idahosa. Thus, American Pentecostal leaders influenced Idahosa; Idahosa influenced Duncan; and Duncan influenced many youths, professionals, pastors and politicians in Africa.

\section{Evidence of the Link from Research Interviews, Analysis and Interpretation}

Two sets of interviews were carried out in the study that directed this article. Firstly, qualitative research was carried out through interviews with 40 contemporary African Neo-Pentecostal leaders drawn from South Africa and Nigeria. Secondly, from the viewpoint of a mother-child relationship — given that most contemporary African NeoPentecostals took their roots from American Neo-Pentecostalism - two medical doctors were interviewed to ascertain the possibility of continuous traits of mothers in children. With this effort the article tries to trace and analyse the current African Neo-Pentecostal practices to their American Neo-Pentecostal roots (mentors). 


\section{Interview with 40 Contemporary African Neo-Pentecostal Leaders}

Forty African Pentecostal leaders were interviewed in a "one-on-one" interaction. ${ }^{1}$ Among them, 90\% are constantly influenced by American Neo-Pentecostal preachers. Also, $62.5 \%$ are influenced by American Pentecostal theology, teaching and preaching. While $10 \%$ are influenced to perform miracles and healing, $10 \%$ are fully under American Pentecostal pastors' mentorship. Additionally, 5\% claim they are influenced to engage in missions and evangelism. Contrarily, $10 \%$ are not influenced at all, while only $2.5 \%$ do not have a specific area of influence.

By interpretation, if $90 \%$ of the African Neo-Pentecostal leaders are influenced by American Pentecostalism, then it suffices to say there is an ongoing ministry connection between African and American Pentecostal preachers. Correspondingly, adding those under American Neo-Pentecostal preachers' direct mentorship to those influenced by the American Neo-Pentecostal televangelists' teaching, preaching and theology, the total number of those fully influenced is $72.5 \%$. This shows that American NeoPentecostal doctrine, whether scripturally accurate or not, has a great influence on contemporary African Neo-Pentecostal leaders and their adherents by extension. Consequently, $90 \%$ of the mentors and influencers listed during the interviews are of the contemporary Neo-Pentecostal faith and prosperity movement in America, while about $10 \%$ are of the Power Evangelism and Holiness Movement of American NeoPentecostals. In summary, the exercise showed that there is a major continuous "dependent link"; African Neo-Pentecostal leaders directly learn and practise some American Neo-Pentecostal religious culture and theology.

\section{Dr Lanre Eletta's Interview on November 30, 2019, in Abuja, Nigeria ${ }^{2}$}

Using the mother-child relations analysis, Dr Lanre held that a foetus depends on the mother as an interface to interact with the outside world through the umbilical cord connection. Through this connection, the child receives oxygen essential for life, and gives back carbon dioxide, a process also required for life. The child also receives nutrients and gives back waste products, the foetus receives immunity and learns to build its own immunity through this connection, but can also receive the mother's illness through that same connection. The mother-child relationship gives the child a foundation to build on, but afterwards the child is left to determine what kind of adult he or she will become. Sadly, some remain attached by a false appearance of a cord that has long been severed. Furthermore, when asked how this mother-child analysis relates to the African and American Neo-Pentecostal relationship, Dr Lanre opined that African Neo-Pentecostals might be trapped at that nine-month period of physical birth to their American Neo-Pentecostal mothers and mentors. At this stage, the relationship is all

1 For ethical reasons, the identity and other details of the interviewees, including their American mentors and spiritual parents, are not disclosed in this article.

2 Dr Eletta Lanre is a surgeon-resident with Advocate Masonic Chicago, USA. He is a Pentecostalpractising lay minister, with Christian leadership experience in House on the Rock (Nigeria) and Redeemed Christian Church of God (Chicago). 
about "garbage-in-garbage-out." This could lead to the alignment of culture, theology or doctrine that permits false practices. In his final words, at conception, a faulty DNA can be handed down to African Neo-Pentecostals by the American Neo-Pentecostals like a mutation.

\section{Dr Sunday Shaibu Interview on December 13, 2019, in Abuja, Nigeria ${ }^{3}$}

The mother-child interaction is in such a way that blood from the baby, which is deoxygenated, comes via the arteries into the mesh of the placenta. In the mesh of the placenta, oxygenated blood from the mother comes and then an interface of diffusion occurs so that the de-oxygenated blood that contains carbon dioxide and all the waste products are exchanged with the oxygenated blood from the mother. So, carbon dioxide and all the impurities go into the mother, while clean oxygen and nutrients from the mother go into the baby and through the baby's veins to have nutrients. Essentially, the blood cells of the baby are carried through the placenta but will never mix up with the mother. Invariably, the baby is an independent being living in the mother, but is totally dependent on the mother for sourcing as a parasitic relationship. When the umbilical cord is cut off after delivery, it cuts the baby loose from the parasitic interaction and the baby now self-exists. When asked how this analysis relates to the African and American Neo-Pentecostal relationship, Dr Shaibu held that African Neo-Pentecostalism needs to self-exist because the mother-child or mentor-learner connection cannot be forever. There is a learning process that the African Neo-Pentecostalism had under American Pentecostalism. However, if it continues, the Americanisation of the gospel will limit the acceptability and evangelisation of the gospel in Africa.

In summary, the interviews with 40 Neo-Pentecostal leaders showed that there is a strong link and continuous influence of the American Neo-Pentecostal leaders on their African counterparts. Correspondingly, the two medical doctors' inputs revealed a strong possibility of transference of traits, culture and theological practices between the American and African Neo-Pentecostals. Worthy of note is the clause of the possibility of self-existence, irrespective of an initial mentor-learner or mother-child link. Now that the link has been established, we will look at the merits and demerits.

\section{Merits of the Link}

There could be more, but this article will list a few merits.

\section{Neo-Pentecostalism Collapsed the Dividing Wall of Racism and Ethnocentrism}

Frank Bartleman, an eyewitness of the Azusa revival, captures the phenomenon of Blacks and Whites worshipping together under a Black pastor without any discrimination. In his words "the color line was washed away in the blood" (Linda

3 Dr Shaibu, is the CEO of Fertil Aid Clinic, Abuja, a fertility and childbirth specialist. He is currently a lay minister (ordained deacon), a trustee and member of Revival House of Glory, Abuja. He is also a graduate of Rhema Bible School, Abuja. 
2010). Correspondingly, this culture reflects among contemporary Neo-Pentecostal churches. People of different tribes and tongues gather in worship without ethnocentric bias. Likewise, as racial hegemony disappears, contextualisation of worship culture is embraced. In other words, adherents embrace harmony of worship with other cultures.

\section{The Neo-Pentecostals are Flexible, Caring and Youth Friendly}

Harvey Cox (BBC 2009, 13 of 17) argues that the great strength of the Pentecostal impulse lies in its power to combine, its aptitude for the language, the music, the cultural artefacts, and the religious tropes of the setting in which it lives. Additionally, the churches work as "mutual aid communities" to deal with poverty, sicknesses, and they provide alternative solutions to problems that might otherwise be "solved" with superstitious practices. Also, flexibility in music and oral worship attracts the youths and students across African universities, who are bored of the liturgical services they attended when back at home with their parents. They appreciate the theology of "let no man despise your youth as theological anchor for youth involvement in Neo-Pentecostal ministries."

\section{Neo-Pentecostalism Takes on Local Costume}

The contextualisation of the gospel is vivid and allows the adherents to interact with the divine via cultural experience. The Pentecostals' acceptance of the value of the body, mind and spirit connections fits well with the non-Christian spiritual background of many developing cultures. It allows incorporation with the elements of those cultures that are compatible with Christianity. The argument then is that Pentecostalism can take on a completely local costume.

\section{The Neo-Pentecostals Engage the Adherents along in Leadership}

Pentecostals have a "flat or flexible power structure" that recognises the priesthood of all believers, where laities have the opportunity to lead certain sacraments. They derived this from Rev. 1:5-6. Consequently, a great sense of belonging and responsibility is stirred up among the adherents. This leadership style has an obvious appeal to those deprived of power or influence at work, in the community or in the political spheres.

\section{The Neo-Pentecostals Engage in Social and Political Transformation Awareness}

Pentecostal theology encourages the empowerment of the poor, freedom from oppression, and confidence to confront injustice. Ellis (2013, 3 of 4) opines, that "the great exception to the general decline in theological influence was the Civil Rights Movement. The theology of suffering was transformed into a weapon against injustice and a tool of empowerment." To date, holding political leadership accountable for injustice, corruption and other social vices is entrenched in Pentecostal theology. Also, participation in political activities, like voting, is strong. 


\section{Neo-Pentecostalism Encourages Evangelism Globally}

From Asia to Africa, South America to the Caribbean, selfless men among the Pentecostals travelled across the world to spread the good news. These power evangelists added value to evangelism as many nations were reached for the first time. As a result, many unbelievers, herbalists and traditional rulers were converted. Pentecostalism created and is still creating the awareness of God through the gospel of Jesus in many traditional idol worship settings in Africa and beyond. Furthermore, the Pentecostals challenged the luke-warmness in mainline denominations. With a degree of certainty, Kojok (2007b, 4 of 4) maintains that God has used the new wave of churches to revive the old denominations.

\section{Demerits of the Link}

There could be more, but this article will list a few demerits.

\section{Focus on Charisma rather than Christ and the Cross}

As may be seen in the case of American Power Evangelists and their mentees across Africa, the selling point of the Neo-Pentecostals is charisma display. Power and gift display are overemphasised, thereby creating the impression that charisma is supreme. Engelsma (2001, 3 of 14) observes that no longer is the preaching of sound doctrine and proper administration of the sacraments the heart of the service; rather, the exuberant praise and the exercise of various gifts under the influence of a freewheeling spirit, are the main things. In addition, Kit (2019, 5 of 6) alludes that there is a shift from the fruits of the spirit to an emphasis on signs and wonders. Ideally, the focus ought to be on Christ and the cross; unfortunately, power display and charisma have become the hallmarks of Neo-Pentecostalism. Thus, the link to and influence of American Power Evangelists on their African mentees are dangerous to the gospel of the cross.

\section{Rise of Manipulation}

Manipulative theology of extortion and exploitation now pervades African NeoPentecostals churches. This can be linked to the influence of American Neo-Pentecostal prosperity theology, especially among the faith movement. This we see in the likes of Jesses Duplantis, Joel Osteen, Kenneth Copeland, Creflo Dollar, and more. This theology of "give and get miracle" "breakthrough and prosperity" has been fully imbibed by African Neo-Pentecostal leaders, who now rank among the richest preachers in the world, while their adherents wallow in abject penury. This is a major deviation from initial classical and holiness Pentecostalism. In an atmosphere of manipulation, charismatic leaders place demands on adherents. With the display of miracles and prophecies, desperate followers will part with their resources in obedience to any instruction. 


\section{Focus on Entertainment}

As earlier stated, overemphasising gifts and charisma above the importance of character, is linked to American Neo-Pentecostal influence. The culture encourages cravings for stardom. In order to sustain stardom, a crowd is needed; and to attract and keep the crowd, entertainment is required. This is how entertainment finds its way into the contemporary African Neo-Pentecostal churches. Currently, comedians are a big part of church services in Africa, especially in Nigeria. While there may be nothing wrong with comedy considering its feel-good factor or economy in the social space, its use to sustain cravings for stardom in the church is appalling. Kit (2019, 5 of 6) points out that entertainment paves the way for shorter sermons, electric atmospheres, shows of signs, wonders and miracles, but less emphasis on a well-considered and well-informed faith. Sadly, these gimmicks are introduced to feed a gullible audience that demands more from the entertainment it consumes than the word of God it deserves. Thus, the centre seizes to be Christ and the cross, but crowd-keeping entertainment. Consequently, adherents' spiritual experience is negatively impacted.

\section{Sole Ownership, Liberalism, Flexibility, and Proliferation}

The administrative structure of contemporary American Neo-Pentecostal churches runs like an individual's business venture. The general overseer (of the church) is regarded as the lord and almighty and he or she holds sole ownership, especially when he or she possesses a measure of charismatic gifts. The charismatic leader submits to nobodyfinancially or doctrinally. This practice is the architect of the commercialisation of the gospel. Likewise, this level of liberality, flexibility and authority makes proliferation easy. Unfortunately, some African Neo-Pentecostal mentees align with their American mentors in this regard. Today, Neo-Pentecostal congregations are scattered all over Africa with theologically untrained general overseers and pastors. In Kojok's view, breakaways are common since the least divergence in doctrine or mode of worship easily leads to separation (Kojok 2007b, 2 of 4). It can be inferred that the number of Pentecostal churches across the globe is not synonymous with spiritual growth. Rather, it reveals the level of liberality, freedom, division and disenfranchising theological malady. As Henri $(2014,209)$ notes: "Pentecostal flexibility and adaptability are the keys to its success, but also the keys to its fragmentation and division." Overall, this culture waters down the quality and positive impact of the gospel in Africa.

\section{Abuse of Spiritual Power in Political Sphere}

The last two presidential elections in America, between 2015 and 2021, reveal the alignment of American Neo-Pentecostals and the political class. The American NeoPentecostal "theology of spiritual authority" positions the charismatic leaders to engage 
prophetically and actively in politics to determine election outcomes. ${ }^{4}$ By influence, the American prophetic-political relationship has been imported into Africa. The sense of spiritual authority and the charismatic power displayed by the African Neo-Pentecostal leaders connect easily with the African politicians, who equally believe in the spirit world. ${ }^{5}$ Thus "symbiotic relationships" are created. The connection makes the political seemingly spiritual and the spiritual obviously political, as the pastors provide spiritual endorsement for politicians. Symbiotically, the politicians build cathedrals, sponsor crusades or conventions and as a return on investment, they use the pastors and congregants for electoral benefits. Asamoah-Gyadu (2006, 4 of 6) gives a good example when he asserts that in African countries like Ghana and Zambia, politicians have courted the friendship of popular charismatic leaders to achieve political ends. Over time, this culture raises questions on the integrity of prophetic ministry in the political space as it influences voter behaviour, dampens the faith of adherents and perhaps permits corruption to the detriment of good governance.

\section{Disastrous Intra and Inter-group Threat and the Disunity of the African Church}

Intra-religious group threat occurs when one or more groups experience the feeling that some group will harm their existence or integrity. From a sociological perspective, Nelson $(2009,2,4)$ identifies two types of group threat; the realistic and the symbolic. The symbolic threat tampers with identity, values, integrity and doctrines. Unfortunately, the consequences of such a threat may be ethnocentrism, intolerance, hatred, fear, anger and resentment. Consequently, the threatened create in-group boundaries, withdrawals, avoidance, aggression, strikes, boycotts or even warfare (see Nelson 2009, 22-23; cf. McCormack 2012, 3-4). Admittedly, learning from America, the contemporary African Neo-Pentecostals have modernised worship via songs, comedies, prophetic and gifts display, and so forth. With such innovations they attract adherents of other denominations, especially the youth. Consequently, "sheep crossover or stealing" becomes inevitable. This easily creates intra and interdenominational threats among the African churches. This level of threat weakens the unity of the Christian body in Africa.

\section{Extremism and Hostility to Common Sense}

American Neo-Pentecostal theology extremely focuses on the supernatural and prophetic inclination. Consequently, it breeds hostility to reason and consultations.

4 This is mostly led by the American Neo-Pentecostal prophetic movement with the likes of Sid Roth and Paula White. See https://www.facebook.com/watch/?v=247214496766003;

https://www.youtube.com/ watch?v=fqgmGfe3Tf4;

https://www.youtube.com/watch?v=yAAbh3VxqKo.

5 See TB Joshua's prophecy on the US election: Trump versus Hilary Clinton at https://www.bbc.com/news/world-africa-37924086. See also Bayelsa State Governor in Nigeria's relationship with TB Joshua for election support at https://www.thecable.ng/lyon-bayelsa-governorelect-visits-t-b-joshua. Likewise, the former president of Ghana visited TB Joshua at the Synagogue for prophetic prayers on electoral victory. See https://www.youtube.com/watch?v=7dj0-26gNB0; https://allafrica.com/stories/200905280654.html. 
Subsequently, Africans adopted this culture easily, based on an initial world view as discussed under the local costume sub-section above. Invariably, many African adherents have been manipulated to suspend their brains in this regard. Where a social responsibility requires common sense to save or move a community forward, spiritual exercise takes precedence. Unfortunately, many African politicians, in alliance with the prophetic Neo-Pentecostal movement, had through this syndrome underdeveloped their nations. This culture creates leeway for civic waste and a lack of strategic thinking. This extremism hinders critical, robust and strategic discussion necessary for problem solving and nation building. Given the above listed and discussed demerits, this article will now make some recommendations.

\section{Recommendations}

\section{The Theological Community Needs to Create a Platform for Dialogue and Pay more Attention to the Activities of the Contemporary Pentecostals}

Theological communities of all denominations and institutions of higher learning need to give more attention to African Pentecostalism and a relationship leading to support systems, like intermittent theological workshops, scholarships for theological degrees and seminars on front burner issues. The support systems can also include a platform for consistent robust dialogue between the academic community, established churches, and Pentecostal leaders. The approach must not be confrontational or condemnatory, otherwise the Pentecostals will shut their doors against any form of interaction.

\section{African Indigenous Pentecostals must Challenge Americanisation of the Gospel using "Sola Scriptura"}

From the historical analysis, this research confirms the existence of indigenous Pentecostalism in Africa. This group needs to collaborate with the theological and academic community to address the disadvantages induced by the link. Most appropriately, the principle of the scriptures as the sole authority for Christian faith and practice must be upheld and weaponised to confront the demerits of African-American Pentecostal link.

\section{African Pentecostals must Disconnect and Consolidate on Africa's Uniqueness}

One of the challenges for Africans is an identity crisis. Most African Pentecostal leaders feel insufficient and inferior. They always believe that whatever comes from the West is better, whether scriptural or not. This situation can be described as "voluntary alignment to spiritual colonisation" as it promotes continuous dependence on American Pentecostal preachers. This demerit is tantamount to burying the uniqueness of African Pentecostalism. The success of African Pentecostalism must be based on "continental uniqueness" and not in her link with American Pentecostalism.

All stakeholders, particularly the theological community, must develop and promote curricula that engender African identity. In addition, the words of Professor Dayo Asaju, 
the Vice Chancellor of Ajayi Crowther University Oyo, support this recommendation, as he argued that "the theology of the West is no longer suitable for us in Africa. Spiritually and biblically, it has damaged faith, seminary and priesthood. Today, we are building cathedrals like in North America, in Asian minor but we are not building people in faith and conviction. There is need to interpret the Bible in a way that will bring development to Africa" (Eyoboka and Latona 2017, 3 of 3). This paper, therefore, recommends that the uniqueness of African Pentecostalism, with the lens of "Sola Scriptura" must be placed above the umbilical relationship with American Pentecostalism. In summary, African Pentecostalism must disconnect and self-exist.

\section{Urgent Need for Theological Training among the Pentecostals and "Church Reform"}

Focus on the spirit world at the expense of theological accuracy must be reversed. Erroneously, using 2 Cor. 3:6, the slogan of many Pentecostal leaders is "the letter kills." However, Paul encouraged Timothy in 2 Tim. 2:15 to study. This article agrees with Ellis (2013, 2 of 4) who asserts that "to apply all of God's word to life is to do theology." Therefore, the role of theological education cannot be overemphasised in this dispensation of doctrinal chaos. The theological community and governments alike must herald the need for theological education among Pentecostal preachers. Where possible, governments should enforce a regulation that provides for theological qualification as a requirement to lead a congregation. Rwanda is a perfect example, where churches were closed for lack of theological merit of the serving clergies (see Woods 2018, 1 of 3). The Rwandan church reform needs to be replicated across Africa. Eradicating the demerits of Pentecostalism cannot be the job of Christian bodies and academic institutions alone; governments' support in terms of enforcing regulations that will promote compliance to the ideal, must be on the frontline.

\section{The Need for Dialogue to Reduce Intra-religion Group Threat}

While mainline churches may disagree with the Pentecostals in many ways, there must be a rallying point as the integrity of the Christian faith and how it is perceived by potential adherents or other religions, takes precedence over intra-group differences. Thus, this article recommends that leadership of Christian bodies across Africa must deliberately engage with Pentecostal leaders in dialogue to discuss issues of intra-intergroup threats. Christian leaders need to come together, renounce hatred, and engage in civil public discourse to promote intra and inter-group peace.

\section{Conclusion}

This article made a strong argument that there was, and there is, a continuous link between African and American Pentecostalism. With the metaphor of the mother-child umbilical relationship, it has been established that certain practices of contemporary Pentecostals in Africa flow from their link with American Pentecostalism. The article further presented the merits and demerits of the link. This research study discovered the genuine motive and passion of the founding fathers and, therefore, concluded that there 


$$
\text { Orogun, Pillay }
$$

is a huge gap between initial and contemporary Pentecostal practices due to American Neo-Pentecostal influence. It finally recommends strategic moves to address the demerits and lauds the need for African Pentecostalism to detach from American Pentecostalism-and self-exist.

\section{References}

Anderson, Allan. 2001. African Reformation: African Initiated Christianity in the 20th Century. Trenton, NJ: Africa World Press.

Asamoah-Gyadu, Kwabena. 2006. "African Pentecostal/Charismatic Christianity: An Overview." Pulse Archives 8 (1). https://www.lausanneworldpulse.com/themedarticlesphp/464/08-2006. https://doi.org/10.1163/9789047406303.

Azusa Street Mission Report. (n.d.). "William J. Seymour.” Azusa Street Mission. https://312azusa.com/historictimeline/william-j-seymour-2/.

BBC. 2009. "Pentecostalism Religions.” Last modified, July 2, 2009. https://www.bbc.co.uk/religion/religions/christianity/subdivisions/pentecostal_1.shtml.

Bruner, Fredrick. D. 1970. A Theology of the Holy Spirit. London: Hodder \& Stoughton.

Coakley, Ebone D. (ed.). 2014. “Testimony: Ebola and John G. Lake.” Modern Ghana. https://www.modernghana.com/lifestyle/7067/testimony-ebola-and-john-g-lake.html.

Ellis, Carl. 2013. "The African American Church: Past, Present, and Future.” Christianity Today. July 11, 2013. https://www.christianitytoday.com/edstetzer/2013/july/africanamerican-church-in-america-past-present-and-future.html.

Engelsma, David. 2001, “Pentecostalism: What Is it?" Protestant Reformed Churches in America: Pamphlets. November 29, 2001. http://www.prca.org/pamphlets/pamphlet_91d.html.

Eyoboka, Sam, and Olayinka Latona. 2017. "African Pentecostalism Perform below Expectation-Experts." Vanguard, June 17, 2017.

https://www.vanguardngr.com/2017/06/african-pentecostalism-perform-expectationexperts/.

Freeman, Dena. 2015. "Pentecostalism and Economic Development in Sub-Saharan Africa." In The Routledge Handbook of Religions and Global Development, edited by Tomalin, Emma. LSE Research Online. 6-15. http://eprints.lse.ac.uk/67826/1/Freeman_Postcolonialism.pdf.

Harvey, Cox. 1996. Fire from Heaven: The Rise of Pentecostal Spirituality and the Reshaping of Religion in the Twenty-First Century. Massachusetts: Reading. 


\section{Orogun, Pillay}

Harrison, Victoria. 2006. "The Pragmatics of Defining Religion in a Multi-cultural World." International Journal for Philosophy of Religion 59 (1): 133-152.

https://www.gla.ac.uk/0t4/humanities/files/mindmapping/Religion1_files/docs/Pragmatics. pdf. https://doi.org/10.1007/s11153-006-6961-z.

Henri, Gooren. 2014. "An Introduction to Pentecostalism: Global Charismatic Christianity." Ars Disputandi 4 (1): 206-209. https://doi.org/10.1080/15665399.2004.10819846.

Idahosa, Margaret. 1995. "Last Honour Speech at the Memorial Service of Daisy Osborn's at Victory Bible Institute, Tulsa Oklahoma, on 1 June 1995.” YouTube Video, January 18, 2020. https://youtu.be/jVegZSX8cfA.

Institute for Advanced Studies in Culture (IASC). N.d. "Colloquy of Religion and Late Modernity: Global Pentecostalism Project. University of Virginia." iasculture.org/research/religion-late-modernity/global-pentecostalism-project.

Isiramen, Celestina O. 2010. Pentecostalism and the Nigerian Socio-Economic Debacle: A Therapy or a Delusion. Ibadan: En-Joy Press \& Books.

Jones, Shannon. 2015. "Christian Charismatic vs. Neo-Charismatics: What Are the Key Differences." Newsmax Media. https://www.newsmax.com/FastFeatures/christiancharismatic-neo-charismatic-key-differences/2015/04/22/id/640162/.

Kalu, Ogbu U. 2002. "Preserving a Worldview: Pentecostalism in the African Maps of the Universe.” Pneuma 24 (2): 110-137. https://doi.org/10.1163/15700740260388009.

Kalu, Ogbu U. 2009. “A Discursive Interpretation of African Pentecostalism.” Fides et Historia 41 (1): 71-90. https://doi.org/10.1093/acprof:oso/9780195340006.003.0004.

Kgatle, Mookgo S. 2017. “African Pentecostalism: The Christianity of Elias Letwaba from early Years until his Death in 1959." Scriptura 116 (1): 1-9. https://doi.org/10.7833/116-11197.

Kit, Kennedy. 2019. "Riding the Third Wave: The Neo-charismatic Movement." Posted April 24, 2019. https://kitkennedy.com/2019/04/24/riding-the-third-wave-the-neo-charismaticmovement/.

Kojok, Justin. 2007a. "The Birth and Effects of Charismaticism in Ghana (I)." Ghanaweb. September 5, 2005. https://www.ghanaweb.com/GhanaHomePage/features/The-Birth-andEffects-of-Charismaticism-in-Ghana-I-116593.

Kojok, Justin. 2007b. "The Birth and Effects of Charismaticism in Ghana (II)." Ghanaweb. September 5, 2007. https://www.ghanaweb.com/GhanaHomePage/features/The-Birth-andEffects-of-Charismaticism-in-Ghana-II-129978.

Linda, Frederick. 2010. "The Colour Line Has Been Washed Away in the Blood." The Celebration. February 21, 2010. https://thecelebration.wordpress.com/2010/02/21/thecolor-line-has-been-washed-away-in-the-blood/. 
Lindbeck, George. 1984. The Nature of Doctrine: Religion and Theology in a Postliberal Age. Louisville: Westminster John Knox Press.

McCormack, Mark M. 2012 "Like Oil and Water: Religious Threat and Prejudice in the American South.” Vanderbilt University institutional Repository, April 16, 2012. hdl.handle.net/1803/11777.

MacRobert, Iain. 1988. "The Roots of Pentecostalism: The American Holiness Movement." In The Black Roots and White Racism of Early Pentecostalism in the USA. London: Palgrave Macmillan.

Morton, Barry. 2017. "Yes, John G Lake Was a Con Man: A Response to Marius Nel." Studia Historiae Ecclesiasticae 43 (2): 1-16. https://dx.doi.org/10.17159/2412-4265/2016/1821.

Nelson, Todd (Ed.). 2009. Handbook of Prejudice, Stereotyping and Discrimination. New Jersey: Lawrence Erlbaum Associates. https://doi.org/10.4324/9781841697772.

Quayesi-Amakye, Joseph. 2016. "A Yeast in the Flour: Pentecostalism as the African Realisation of the Gospel." Studia Historiae Ecclesiasticae 42 (3): 71-84. https://doi.org/10.17159/2412-4265/2016/1591.

Relate-(Bp). 2016. "Biography of Archbishop Benson Andrew Idahosa." Believers' Portal. September 8, 2016. https://believersportal.com/biography-of-archbishop-benson-andrewidahosa/.

Robinson, Bruce A. 2000. "History of Pentecostalism. Religious Tolerance." Last updated April 11, 2000. http://www.religioustolerance.org/chr_pent.htm.

Roger, Robins G. 1990. "Pentecostal Movement." In Dictionary of Christianity in America, edited by Daniel G. Reid. Downers Grove, IL: Intervarsity Press.

Sundkler, Bengt. 1976. Zulu Sion and some Swazi Zionists. London: Oxford University Press.

Synan, Vinson. 1980. “Introduction.” In Azusa Street: The Roots of Modern-day Pentecost, edited by Frank Bartleman. Plainfield, New Jersey: Logos International.

Synan, Vinson. 2019. "The Origins of the Pentecostal Movement. The Mechanics of Faith." Last updated June 26, 2019. https://www.hopefaithprayer.com/word-of-faith/originspentecostal-movement/.

Towns, Joe. 2006. “Talking Pentecostalism.” Blogger, October 28, 2006. https://talkingpentecostalism.blogspot.com/2006/10/what-is-pentecostalism.html.

Woods, Mark. 2018. "Why has Rwanda closed 8,000 Christian Churches?" Christian Today. Posted August 17, 2018. https://www.christiantoday.com/article/why-has-rwanda-closed8000-christian-churches/130243.htm. 